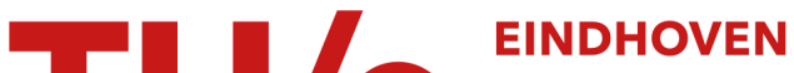 \\ UNIVERSITY OF \\ TECHNOLOGY
}

\section{Periodic Layer Formation during Solid State Reactions}

Citation for published version (APA):

Rijnders, M. R., Kodentsov, A., Cserhati, C., Akker, van den, J., \& Loo, van, F. J. J. (1996). Periodic Layer Formation during Solid State Reactions. Diffusion and Defect Data. Part A, Defect and Diffusion Forum, 129130, 253-266. https://doi.org/10.4028/3-908450-16-0.253

DOI:

10.4028/3-908450-16-0.253

Document status and date:

Published: 01/01/1996

\section{Document Version:}

Publisher's PDF, also known as Version of Record (includes final page, issue and volume numbers)

\section{Please check the document version of this publication:}

- A submitted manuscript is the version of the article upon submission and before peer-review. There can be important differences between the submitted version and the official published version of record. People interested in the research are advised to contact the author for the final version of the publication, or visit the $\mathrm{DOI}$ to the publisher's website.

- The final author version and the galley proof are versions of the publication after peer review.

- The final published version features the final layout of the paper including the volume, issue and page numbers.

Link to publication

\section{General rights}

Copyright and moral rights for the publications made accessible in the public portal are retained by the authors and/or other copyright owners and it is a condition of accessing publications that users recognise and abide by the legal requirements associated with these rights.

- Users may download and print one copy of any publication from the public portal for the purpose of private study or research.

- You may not further distribute the material or use it for any profit-making activity or commercial gain

- You may freely distribute the URL identifying the publication in the public portal.

If the publication is distributed under the terms of Article 25fa of the Dutch Copyright Act, indicated by the "Taverne" license above, please follow below link for the End User Agreement:

www.tue.nl/taverne

Take down policy

If you believe that this document breaches copyright please contact us at:

openaccess@tue.nl

providing details and we will investigate your claim. 


\section{Periodic Layer Formation during Solid State Reactions}

M.R. Rijnders' ${ }^{1}$, A.A. Kodentsov ${ }^{1}$, Cs. Cserháti ${ }^{2}$, J. van den Akker ${ }^{1}$

1 Laboratory of Solid State Chemistry and Materials Science, Eindhoven University of Technology, PO Box 513, NL-5600 MB, Eindhoven, The Netherlands

2 Department of Solid State Physics, Lajos Kossuth University, PO Box 2, H-4010 Debrecen, Hungary

Keywords: Interfacial Dynamics, Periodic Pattern, Kirkendall Effect, Diffusion Induced Stress

\section{Abstract}

The periodic layered morphology is presented as a new type of reaction layer morphology for solid state reactions. This morphology is shown to occur in several ternary and higher order diffusion couples and the morphological features are considered in detail. Some early explanations are discussed and an attempt is made to link all observed features to existing theories on diffusion phenomena and defect motion.

\section{Introduction}

Solid reaction products of solid/solid reactions may appear in a variety of morphologies. In binary multiphase diffusion couples only single phase layers can be formed during solid state reactions. The additional component in a ternary diffusion couple provides one extra degree of freedom which allows for the appearance of different structures within the diffusion zone. Three types of reaction product morphologies have been described in detail: 1) layered; 2) isolated precipitates in a single-phase layer; 3) interpenetrating columnar (lamellar) or interwoven structure. Those types are very common and conditions governing the formation of these are well understood $[1,2,3,4]$.

Periodic layer formation during solid state reactions was discovered in the beginning of the eighties [5]. The periodic layered morphology consists of regularly spaced layers of particles of one reaction product embedded in a matrix phase (another reaction product). Such unusual pattern formation has not been widely met and the explanations that have been put forward are still lacking a sound basis. The number of systems that is known to produce the periodic layered structure is small but increasing and includes a variety of metal/metal and metal/ceramic reactions. In the present paper we systematize the experimental results obtained from various diffusion couples where this periodic pattern was observed and discuss possible explanations of this unusual phenomenon.

\section{Experimental}

Throughout the investigation the diffusion couple technique has been used. Planparallel slices of the as-supplied and/or arc-melted homogeneous polycrystalline materials were clamped together and annealed for varying times and at various temperatures. Different atmospheres were used ( $\mathrm{He}$ or $\mathrm{Ar}$ in the zinc and magnesium containing couples, vacuum for $\mathrm{SiC} / \mathrm{Pt}$ couples). The couples were allowed to cool to room temperature, cut with a slow-speed saw and prepared for microscopical examination by standard metallographic techniques. Cross-sections were taken both parallel and perpendicular to the diffusion direction. Polarized light microscopy, SEM, EPMA and TEM were used in investigating the samples. 
Reactions in the systems $\mathrm{Zn} / \mathrm{Me}$-silicide $(\mathrm{Me}=\mathrm{Fe}, \mathrm{Co}, \mathrm{Ni})$

1. $\mathrm{Fe}_{3} \mathrm{Si}+\mathrm{Zn}$

The first example of a periodic layered morphology was found in an investigation on the influence of Si on the solid state reaction of zinc with iron [6]. A change was found in the reaction layer morphology when the Si-content of the $\mathrm{Fe}(\mathrm{Si})$ solid solution was gradually increased from 0 to 25 at.\% (solubility limit for $\mathrm{Si}$ in $\mathrm{Fe}$ at $395^{\circ} \mathrm{C}$ ). When $\mathrm{c}_{\mathrm{si}} \leq 0.4$ at.\% no difference in reaction layer morphology with that of $\mathrm{Fe}-\mathrm{Zn}$ diffusion couples is found. At $c_{\mathrm{si}}=2.3$ at. $\%$ small particles appear inside the $\zeta$ phase. At $c_{\mathrm{si}}=9.0$ at. $\%$ a two-phase

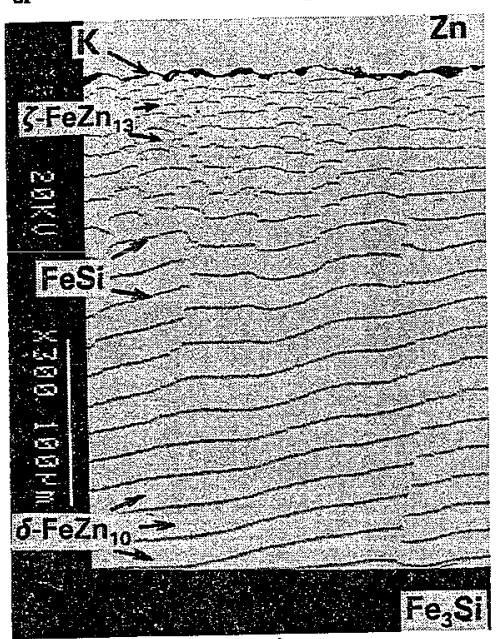

a)

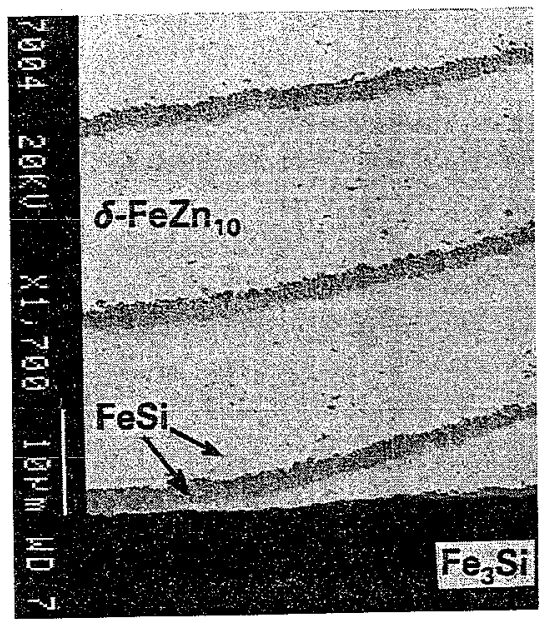

c)

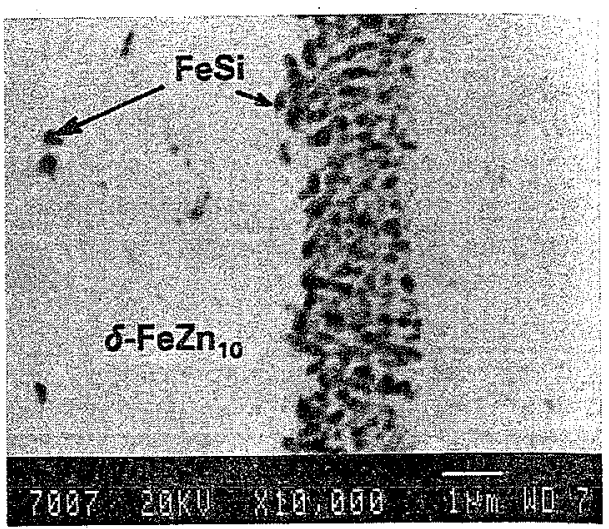

b)

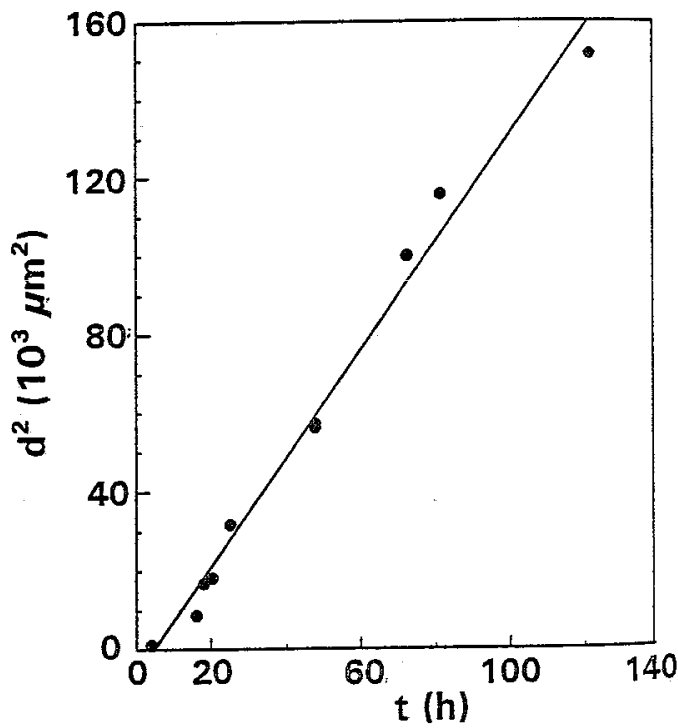

d)

Fig. 1 Backscattered Electron Images (BEI) of the reaction zone in a $\mathrm{Fe}_{3} \mathrm{Si} / \mathrm{Zn}$ diffusion couple annealed for $96 \mathrm{~h}$ at $663 \mathrm{~K}$ in He; a) general view; b) magnification of a band, showing it is two-phase; c) magnified area close to the $\mathrm{Fe}_{3} \mathrm{Si}$ substrate. $\mathrm{K}$ indicates Kirkendall plane.

d) time dependence of the reaction layer thickness at $663 \mathrm{~K}$. 
20ne $\left(\mathrm{Fe}_{3} \mathrm{Si}+\delta\right)$ develops next to the substrate and $\mathrm{FeSi}$ particles are present in the old part of the reaction zone. At $\mathrm{c}_{\mathrm{si}}=17.9$ at. $\%$ the whole reaction zone contains precipitates, at $c_{\mathrm{si}}=23.2$ at.\% the onset of periodic layer formation can be seen and at $c_{\mathrm{si}}=25$ at. $\%$ the periodic layered morphology is observed. In fig. 1a the morphology in a solid-solid diffusion couple between $\mathrm{Fe} 3 \mathrm{Si}$ (in fact a $\mathrm{Fe}(\mathrm{Si})$ ordered $\left(\mathrm{DO}_{3}\right)$ solid solution) and zinc after annealing at $663 \mathrm{~K}$ for $96 \mathrm{~h}$ is given.

The reaction layer itself consists of two main layers which are the usual $\delta$-FeZn $\mathrm{Zn}_{10}$ and $\zeta$ $\mathrm{FeZ}_{13}$ phases. Inside these phases thin bands are found, consisting of FeSi particles. The bands can be continuous over hundreds of microns. The width of the bands is about 1.5-2 $\mu \mathrm{m}$. The average distance between the bands is about $16 \mu \mathrm{m}$. However, different spacings can be found in the zone opposite different grains of $\mathrm{Fe}_{3} \mathrm{Si}$. Those differences correspond to different grain orientations of $\mathrm{Fe}_{3} \mathrm{Si}$. From fig. $1 \mathrm{~b}$, which is a magnification of a single phase. Some of the particles are present also in between bands. It is observed that the bands break off very close to the $\mathrm{Fe}_{3} \mathrm{Si}$ /two-phase zone interface, i.e. the $\mathrm{Fe}_{3} \mathrm{Si}$ is permanently covered by a very thin two-phase layer (fig. 1c).

Results of layer growth measurements are plotted in fig. 1d. From this graph one may conclude that the total layer grows parabolically with time at $663 \mathrm{~K}$, indicating a diffusion controlled mechanism. The Kirkendall plane is revealed by the row of pores, always located close to the $\mathrm{Zn} / \zeta$ interface, proving that zinc is the most mobile species in the $\zeta$ phase.

The formation of a periodic structure in this system is not restricted to the temperature 663 $\mathrm{K}$. It was also observed at lower and higher temperature, e.g. at $723 \mathrm{~K}$, above the melting point of zinc. The latter observation indicates that the physical state of the zinc has no influence on the presence of bands in this temperature range [5].

2. $\mathrm{Co}_{2} \mathrm{Si}+\mathrm{Zn}$

A striking pattern was observed in the diffusion couple $\mathrm{Co}_{2} \mathrm{Si} / \mathrm{Zn}$ after annealing at $663 \mathrm{~K}$ [7]. The reaction zone (with phases $\mathrm{CoSi}, \gamma_{1}\left(\mathrm{CoZn}_{8}\right)$ and $\gamma_{2}\left(\mathrm{CoZn}_{13}\right)$ ) consists of a number of cells with different morphologies (fig. 3a). Some are regular and consist of parallel alternating layers, some are irregular but a certain kind of periodicity can still be observed. The bands are two-phase layers and contain small precipitates of CoSi inside a matrix of $\gamma_{1}$ or $\gamma_{2}$ (fig. 3a,b). No particles of CoSi were detected between the bands in the $\mathrm{Co}_{\mathrm{Z}} \mathrm{Zn}$ intermetallic matrix with SEM.

The band spacing differs from cell to cell. It varies from $\sim 4 \mu \mathrm{m}$ (minimum) up to $\sim 20$ $\mu \mathrm{m}$. Band width and spacing occur in different proportions but in each cell the spacing is nearly constant. The areas which have the smallest spacings are invariably the widest, i.e. they have grown fastest. Along the zinc-side and extending over the complete diffusion zone always a very tiny band is present. Most likely this is the first band to be formed. It was found that cells of different morphology form on different grains of the orthorhombic [8] dicobaltsilicide. This points to a possible crystallographic relation between the observed periodicity and the orientation of the $\mathrm{CO}_{2} \mathrm{Si}$ grains. The effect is much stronger than with the (cubic) $\mathrm{Fe}_{3} \mathrm{Si}$. However, no quantitative relationship has been established yet.

When viewing the reaction zone in a plane perpendicular to the diffusion direction one can see a pattern of CoSi precipitates in the $\gamma_{2}$ matrix (fig. 2c). Most likely this pattern can be connected with precipitation of $\mathrm{CoSi}$ particles on macroscopic dislocation loops present in the starting material $\mathrm{Co}_{2} \mathrm{Si}$. This pattern is only found on some grains (grain boundaries are visible in fig. $2 \mathrm{c}$ ) of the underlying $\mathrm{CO}_{2} \mathrm{Si}$, reflecting the influence of grain orientation. More often, only chaotic patterns are found in this kind of cross-section. 


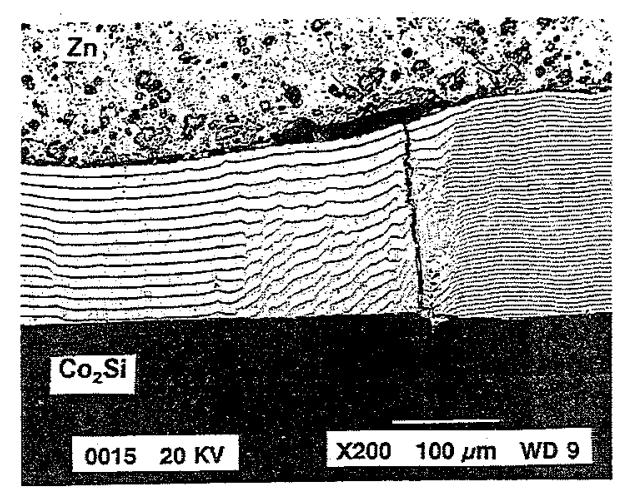

a)

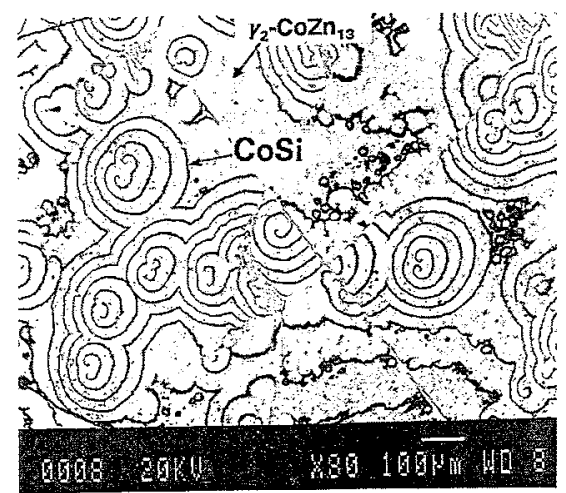

c)

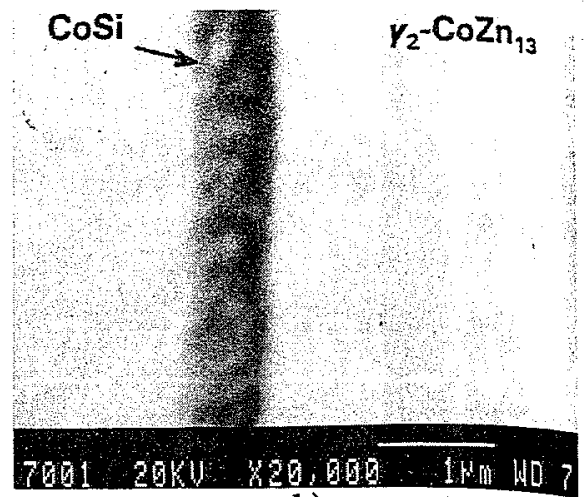

b)

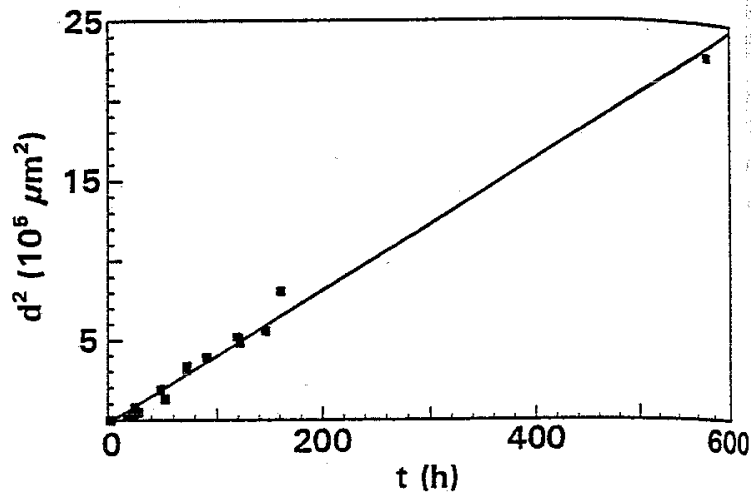

d)

Fig. $2 \mathrm{BEI}$ of the reaction zone between $\mathrm{Co}_{2} \mathrm{Si}$ and $\mathrm{Zn}$ after annealing for $28 \mathrm{~h}$ at $663 \mathrm{~K}$ in $\mathrm{He}$; a) general view; b) morphology of the two-phase $\left(\mathrm{CoSi}+\gamma_{2}\right)$ band; c) crosssection of reaction layer perpendicular to the diffusion direction; d) time dependence of the reaction layer thickness at $663 \mathrm{~K}$

The growth rate of the reaction zone differs from cell to cell. In fig. $2 \mathrm{~d}$ the growth kinetics of the widest layer present in any investigated $\mathrm{Co}_{2} \mathrm{Si} / \mathrm{Zn}$ diffusion couple is given. The total layer thickness follows a parabolic growth law that implies a diffusion controlled growth mechanism.

\section{3. $\mathrm{Ni}_{3} \mathrm{Si}_{2}+\mathrm{Zn}$}

This is the finest periodic layered structure (with a spacing of $\sim 1 \mu \mathrm{m}$ ) found up till now in solid state diffusion couples (fig. 3a). The morphology is characterized by a regular array of bands of particles of a Si-rich phase (dark contrast in the backscattered electron images (BEI)) embedded in the matrix of a Ni-Zn intermetallic. It can be seen from the micrographs that spacing between bands slightly increases towards the $\mathrm{Zn}$-side of the transition zone. Three two-phase layers consisting of Si-rich precipitates inside different intermetallic matrices can be distinguished just by their appearance in the BEI (fig. 3b). The formation of a periodic structure occurs only in the two-phase layer adjacent to the $\mathrm{Ni}_{3} \mathrm{Si}_{2}$ substrate. In traversing the diffusion zone from the $\mathrm{Ni}_{2} \mathrm{Si}_{3} /$ reaction layer interface, the periodic pattern disintegrates into random distributed particles of Si-rich phase within a $\mathrm{Zn}$-rich layer. A thin precipitate-free zone of $\delta-\mathrm{NiZn}_{8}$ was observed in the vicinity of the $\mathrm{Zn} / \delta-\mathrm{NiZn}_{8}$ interface. Attempts to determine the chemical composition of the phases 
within the two-phase layers (except $\delta-\mathrm{NiZn}_{8}$ ) were inconclusive due to the limited spatial resolution of the Electron Probe Microanalysis. The phase relations in the ternary Ni-Si-Zn system at $663 \mathrm{~K}$ are not known which makes it difficult to describe the morphological development in this diffusion couple.

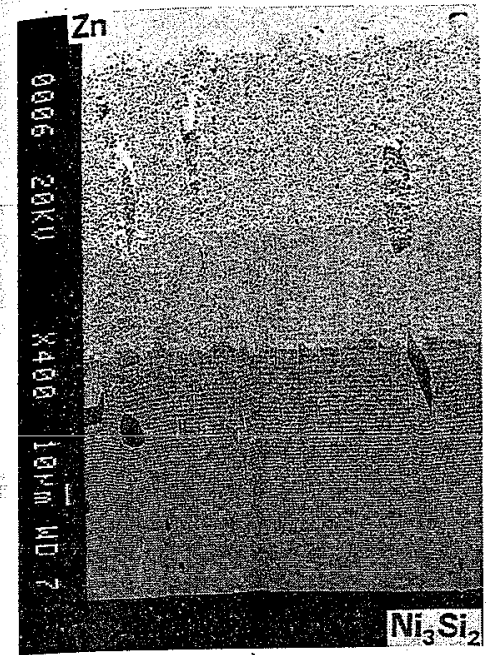

a)

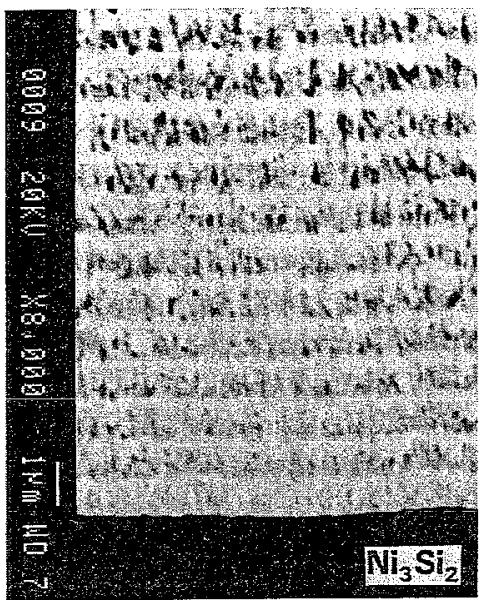

b)

Fig. $3 \mathrm{BEI}$ of the reaction zone between $\mathrm{Ni}_{3} \mathrm{Si}_{2}$ and $\mathrm{Zn}$ after annealing for $72 \mathrm{~h}$ at $663 \mathrm{~K}$ in $\mathrm{Ar}$; a) general view; b) magnified area close to the $\mathrm{Ni}_{3} \mathrm{Si}_{2} /$ reaction layer interface

\section{Interaction of $\mathrm{Mg}$ with $\mathrm{Ni}-\mathrm{Co}-\mathrm{Fe}$ alloys}

Reactions of magnesium with Ni-Co and Ni-Co-Fe alloys at $725 \mathrm{~K}$ have been investigated intensively $[9,10,11]$. We investigated $\mathrm{Mg} / \mathrm{Ni}_{50} \mathrm{Co}_{20} \mathrm{Fe}_{30}$ couples at $733 \mathrm{~K}$ and found the same type of periodic layered morphology (fig. 4). There is a regular periodic array of bands (of width $-3 \mu \mathrm{m}$ ) of particles inside a matrix phase. The band spacing is about $7 \mu \mathrm{m}$ and varies a little bit over the reaction zone. Many particles are also present in between the bands.

The phase composition of the precipitates in the hexagonal $\mathrm{Mg}_{2} \mathrm{Ni}$ matrix was determined by analytical electron microscopy (AEM, TEM). A characteristic X-ray spectrum and corresponding selected area electron diffraction patterns taken from the particles are shown in fig. 5. They reveal that the particles do not contain any $\mathrm{Mg}$ and consist of cubic $\mathrm{Fe}-\mathrm{Co}(\mathrm{Ni})$ solid solution (presumably the $\mathrm{CsCl}$ ordered structure).

The thickness of the total reaction layer in the $\mathrm{Mg} / \mathrm{Ni}_{50} \mathrm{CO}_{20} \mathrm{Fe}_{30}$ couple at $733 \mathrm{~K}$ follows the parabolic law (fig. 6) i.e. the reaction is diffusion controlled. The Kirkendall plane is clearly visible inside the $\mathrm{Mg}_{2} \mathrm{Ni}$ intermetallic close to the $\mathrm{Mg}_{2} \mathrm{Ni} / \mathrm{Mg}$ interface (fig. 4a). This proves that $\mathrm{Mg}$ is the most mobile component in $\mathrm{Mg}_{2} \mathrm{Ni}$ although $\mathrm{Ni}$ atoms also diffuse appreciably. No $(\mathrm{Fe}, \mathrm{Co})$ precipitates are present on the Mg-side of the Kirkendall plane.

It can be seen from fig. $4 \mathrm{~b}$ that the appearance of the periodic structure originates from a repeated "cracking" of the interwoven (Fe,Co) bands close to the $\mathrm{Ni}_{50} \mathrm{Co}_{20} \mathrm{Fe}_{30}$ face. A lifting off occurs when the layer reaches a certain critical thickness. A relatively thick (a few $\mu \mathrm{m})$ two-phase layer still adheres to the initial alloy. We also see that the particles of the adhering band get coarser in the direction of $\mathrm{Mg}$.

Varying the composition of the Ni-Co-Fe alloy can change the layered morphology 


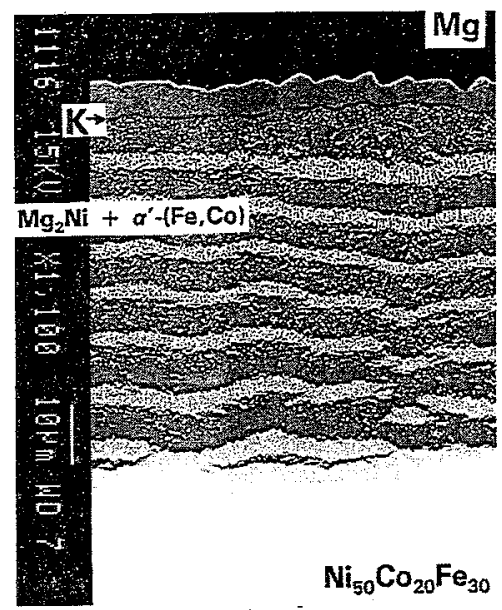

a)

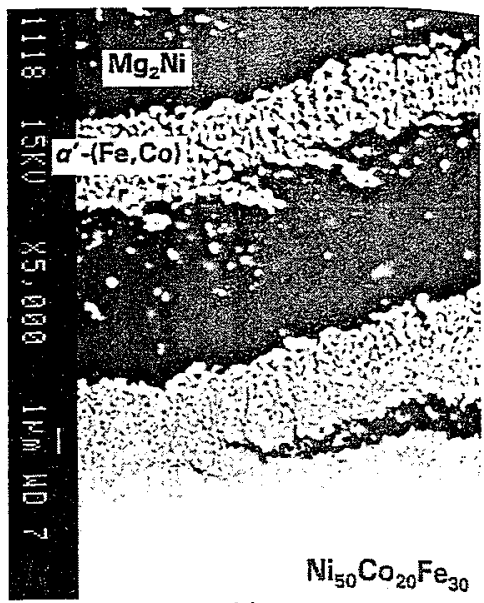

b)

Fig. $4 \mathrm{BEI}$ of the transition zone between $\mathrm{Mg}$ and $\mathrm{Ni}_{50} \mathrm{Co}_{20} \mathrm{Fe}_{30}$ annealed for $72 \mathrm{~h}$ at $733 \mathrm{~K}$ in $\mathrm{Ar}$; a) general view; b) magnified area of the diffusion zone close to the alloy/reaction zone interface (Letter $\mathrm{K}$ indicates Kirkendall plane)

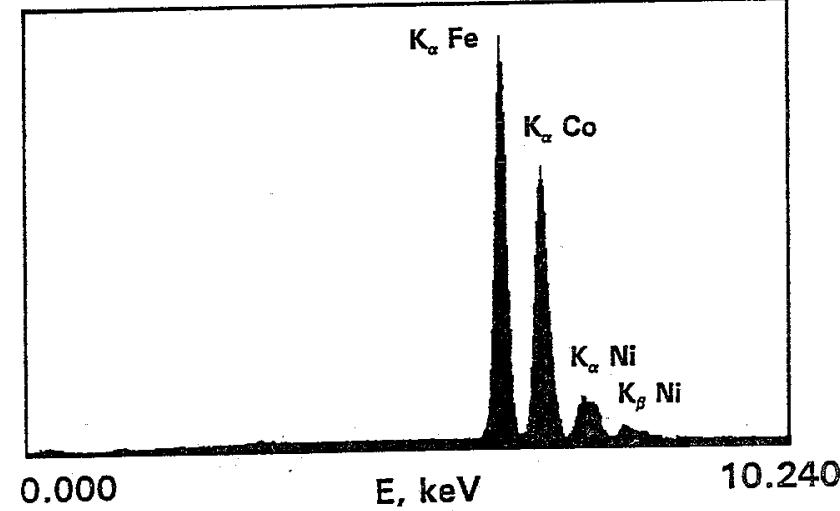

F

a)

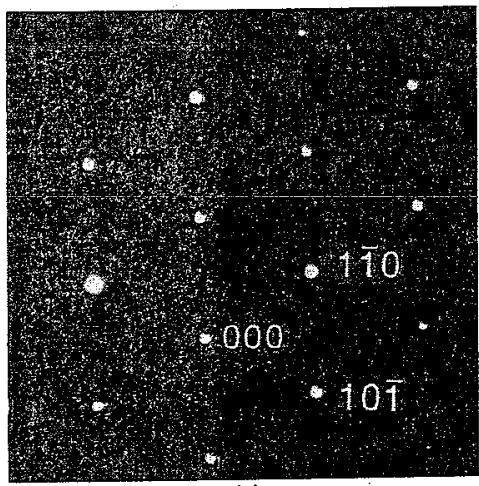

b)

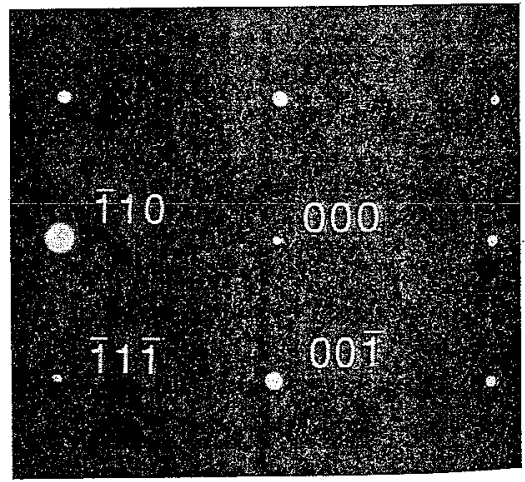

c)

Fig. 5 Characteristic X-ray spectrum (a) and selected area diffraction patterns taken from particles forming the periodic band in $\mathrm{Mg} / \mathrm{Ni}_{50} \mathrm{Co}_{20} \mathrm{Fe}_{30}$ diffusion couple. Indexed as b) [111] and c) [110] directions in $\alpha^{\prime}-(\mathrm{Fe}, \mathrm{Co})$ solid solution. 
drastically. Whereas $\mathrm{Ni}_{60} \mathrm{Co}_{20} \mathrm{Fe}_{20}$ still gives a periodic layered structure, other compositions of the alloy result in less bands $\left(\mathrm{Ni}_{40} \mathrm{CO}_{20} \mathrm{Fe}_{40}\right)$ or no bands at all $\left(\mathrm{Ni}_{60} \mathrm{Co}_{10} \mathrm{Fe}_{30}\right.$ and $\left.\mathrm{Ni}_{40} \mathrm{CO}_{30} \mathrm{Fe}_{30}\right)$. We also found that the addition of 1 at.\% tungsten to $\mathrm{Ni}_{50} \mathrm{CO}_{20} \mathrm{Fe}_{30}$ results in
the total suppression of band formation.

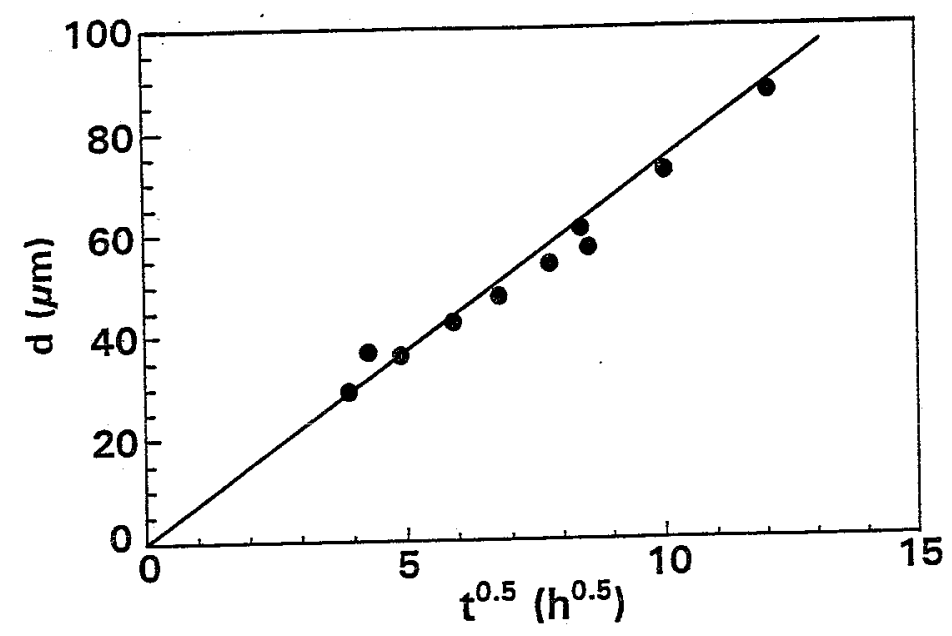

Fig. 6 Time dependence of reaction layer thickness in the diffusion couple $\mathrm{Mg} / \mathrm{Ni}_{50} \mathrm{Co}_{20} \mathrm{Fe}_{30}$ at $733 \mathrm{~K}$

\section{Reaction of non-carbide forming metals with $\mathrm{SiC}$}

The first example of a banded morphology in metal/ceramic reactions was reported by Mehan and Jackson [12]. Their investigation concerned reactions of $\mathrm{SiC}$ with $\mathrm{Ni}$ and $\mathrm{Ni}-\mathrm{Cr}$ Al alloys. It is notheworthy to mention that they also found an influence of the presence of tungsten on the band formation. Reactions of $\mathrm{SiC}$ with pure $\mathrm{Fe}$ [13] or $\mathrm{Co}$ [14] on the other hand, produce a reaction zone with randomly distributed carbon particles.

Chou has reported the "anomalous" reaction between $\mathrm{SiC}$ and $\mathrm{Pt}$ over the temperature range $1173-1273 \mathrm{~K}[15,16]$. This is above the eutectic temperature in the binary Pt-Si system [17]. The formation of periodic structures consisting of alternating layers of Ptsilicides and carbon (graphite) was observed in the reaction zone. The author supposed that such a morphology might originate '...from solidification of the interfacial melt when the diffusion couple was air cooled'. The graphite aggregates have been attributed to precipitation of carbon from $\mathrm{Pt}_{3} \mathrm{Si}$ upon solidification due to its low solubility in this phase. The present work focuses on the unusual behaviour of carbon during the solid state interaction of $\mathrm{SiC}$ and $\mathrm{Pt}$ over the temperature range 973-1023 $\mathrm{K}$. The experimentally determined isothermal cross-section through the ternary Pt-Si-C phase diagram is shown in fig. 7a. In the reaction between $\mathrm{Pt}$ and $\mathrm{SiC} \mathrm{Pt}_{3} \mathrm{Si}, \mathrm{Pt}_{7} \mathrm{Si}_{3}$ and $\mathrm{Pt}_{2} \mathrm{Si}$ are formed, whereas graphite is found in two-phase bands. At the $\mathrm{Pt}_{2} \mathrm{Si} / \mathrm{SiC}$ interface always graphite is present. Since in graphite the thermodynamic activity of carbon is unity and in SiC lower than one it is impossible that graphite is formed at the metal side, since then carbon would have to diffuse intrinsically against the gradient of its chemical potential. Thus graphite formed by the interfacial reaction will stay next to the $\mathrm{SiC}$. However in practice it turns out that carbon is found in the form of graphite not only next to the $\mathrm{SiC}$ but also through the $\mathrm{Pt}_{7} \mathrm{Si}_{3}$ layer in the form of two-phase bands, up to the Kirkendall plane. This is situated inside 


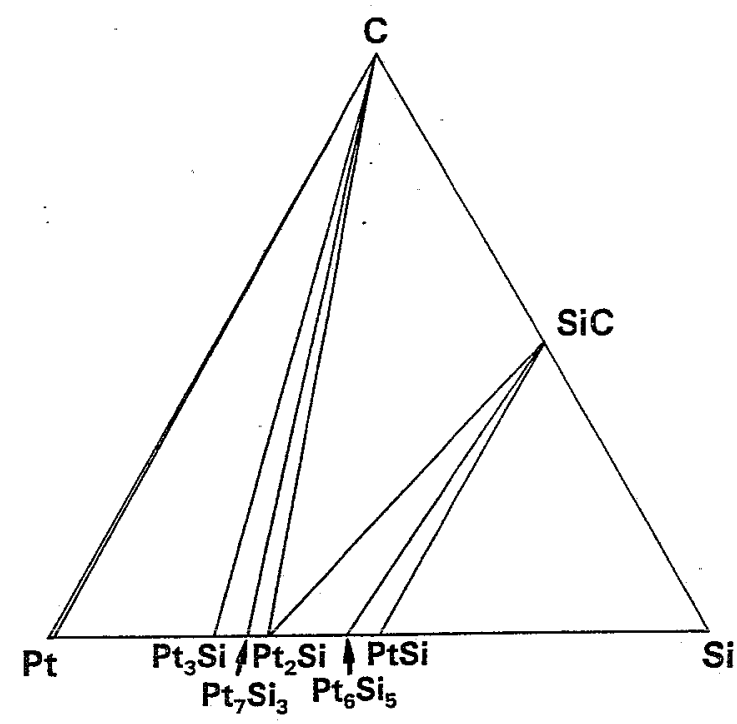

a)

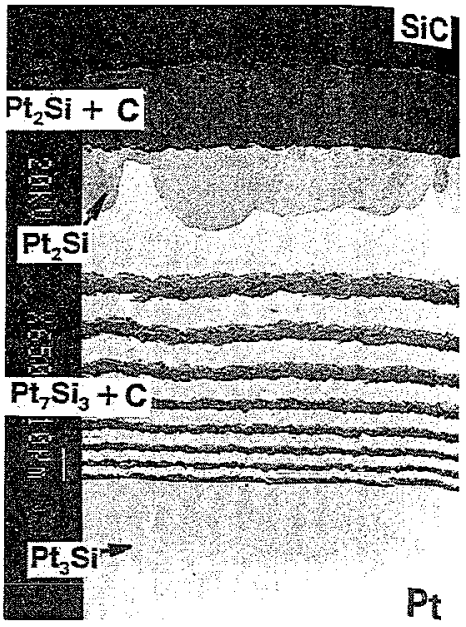

b)

Fig. 7 a) Isothermal cross-section through the Pt-Si-C diagram over the temperature range 973-1023 K. Pt $\mathrm{Si}$ exists as $\alpha$ at $973 \mathrm{~K}$ and as $\beta$ at $1023 \mathrm{~K}$; b) morphology of reaction zone in an SiC/Pt diffusion couple annealed for $24 \mathrm{~h}$ at $1023 \mathrm{~K}$ in vacuum (BEI)

$\mathrm{Pt}$

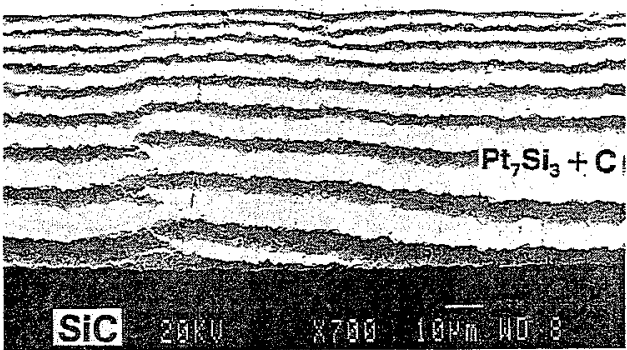

a)

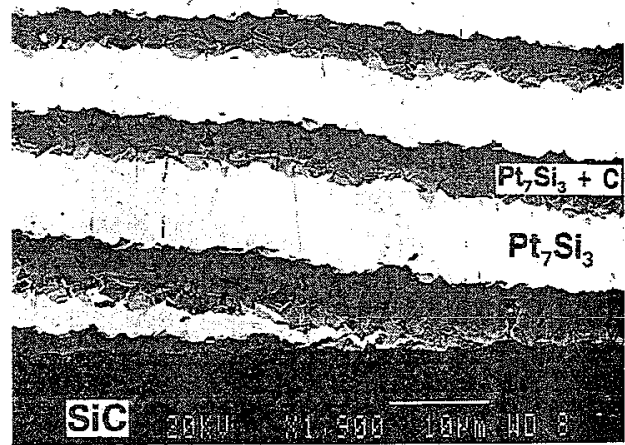

b)

Fig. $8 \mathrm{BEI}$ of the diffusion zone between $\mathrm{Pt}$ and $\mathrm{SiC}$ after annealing at $973 \mathrm{~K}$ for $25 \mathrm{~h}$ in vacuum; a) general view; b) magnified area of the reaction zone close to the $\mathrm{SiC}$ interface

$\mathrm{Pt}_{7} \mathrm{Si}_{3}$, close to the interface with $\mathrm{Pt}_{3} \mathrm{Si}$, which implies that $\mathrm{Pt}$ is the most mobile species in $\mathrm{Pt}_{7} \mathrm{Si}_{3}$. It is observed that $\mathrm{Pt}_{2} \mathrm{Si}$ grows in a quite irregular fashion. When the thickness of the $\mathrm{Pt}_{2} \mathrm{Si}$ exceeds the thickness of the graphite-containing layer adjacent to the $\mathrm{SiC}$ the formation of bands is stopped.

A characteristic feature of the reaction pattern is that the distance between the graphitecontaining bands increases gradually towards the SiC-side of the couple. Another interesting result may be seen from fig 8 . When the two-phase layer has reached a certain critical thickness cracking in the interwoven graphite band occurs. The shape of the 
interface between $\mathrm{Pt}_{7} \mathrm{Si}_{3}$ and the newly formed mixed $\mathrm{Pt}_{7} \mathrm{Si}_{3}+\mathrm{C}$ band is an exact replica of the $\left(\mathrm{Pt}_{7} \mathrm{Si}_{3}+\mathrm{C}\right)$ layer that remains at the $\mathrm{SiC}$ interface. This is true for all graphitecontaining bands.

phase growth is diffusion controlled (fig. 9). In a $\mathrm{Pt} / \mathrm{SiC}$ diffusion couple annealed at $973 \mathrm{~K}, \mathrm{Pt}_{2} \mathrm{Si}$ could not be observed directly. However, the Pt:Si ratio (as measured by EPMA) inside the carbon-containing band adjoining the $\mathrm{SiC}$ was found to be about $2: 1$, while a ratio of 7:3 was measured within the same layer but close to the $\mathrm{Pt}_{7} \mathrm{Si}_{3}$-side. This indicates that at $973 \mathrm{~K} \mathrm{Pt} \mathrm{Si}_{2}$ is also formed, but as a thin layer. This remarkable difference in growth rate can be attributed to the diagram the transition temperature lies at $968 \pm 5 \mathrm{~K}$ [17]. Obviously a significant difference
[ in growth kinetics exists between the HT and LT modifications.

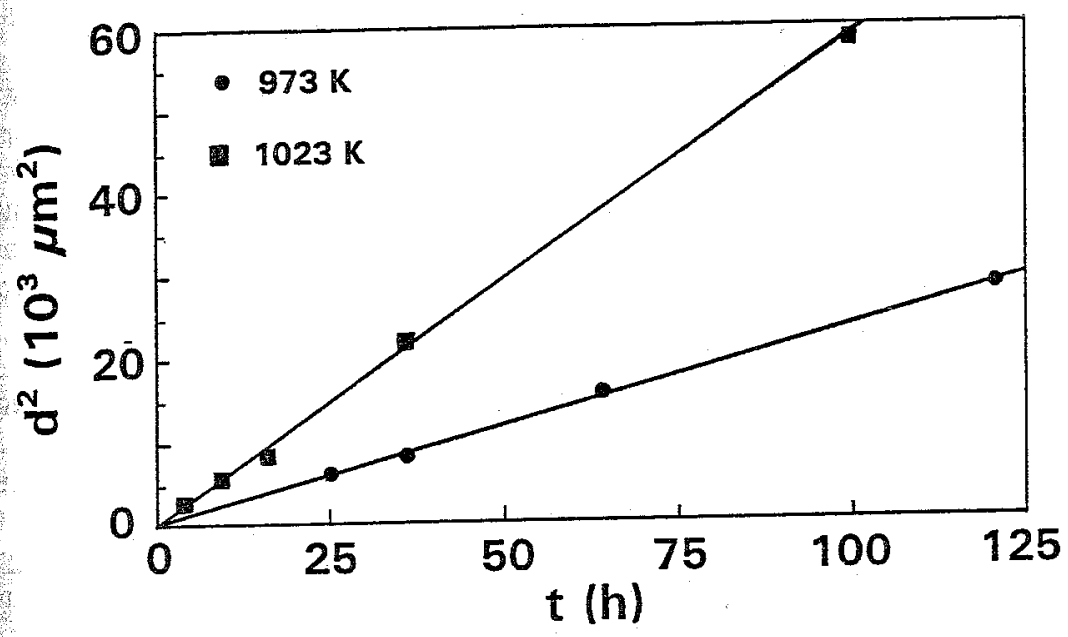

Fig. 9 . Time dependence of the reaction layer thickness in SiC/Pt diffusion couples at 973 and $1023 \mathrm{~K}$

The Kirkendall effect in diffusion-driven phase transformations and periodic pattern formation

The systems described above all exhibit the same type of phase diagram and large differences in mobilities of the components. The common feature of the corresponding diffusion zones is that they consist of a periodic arrangement of two-phase bands. Periodic structures in which the bands consist of single-phase layers are not observed.

Referring to the work of Osinski et al. [5], Kirkaldy [18] considered this type of reactions to be a Liesegang phenomenon [19]. For a Liesegang mechanism, the spacing of bands should obey the Jablczynski relation [20]:

$$
\mathrm{x}_{\mathrm{n}} / \mathrm{x}_{\mathrm{n}-1}=\mathrm{k}
$$

Where $x_{n}$ is the distance of the $n$-th band from the original interface and $k$ is a constant. It can be shown that the band spacing in the $\mathrm{Pt} / \mathrm{SiC}$ couples (where $\mathrm{x}_{\mathrm{n}}$ is measured as the distance to the Kirkendall-plane) obeys this relation. However in the other described 
systems it does not. More evidence that the periodic layer formation is not a Liesegang phenomenon can be seen from figs. $1 \mathrm{c}, 4 \mathrm{~b}$ and $8 \mathrm{~b}$. A two-phase layer $\left(\delta-\mathrm{Fe} \mathrm{Zn}_{10}+\mathrm{FeSi}\right.$ $\left.\mathrm{Mg}_{2} \mathrm{Ni}+\alpha^{\prime}-(\mathrm{Fe}, \mathrm{Co}), \mathrm{Pt}_{7} \mathrm{Si}_{3}+\mathrm{C}\right)$ is still present at the initial "substrate" when the previous one has been released. According to the Liesegang mechanism a new band is not formed until a critical supersaturation has been built up $[21,22]$. This is obviously not the case in the systems discussed here and thus a Liesegang mechanism may be excluded. The appearance of a periodic pattern rather originates from a repeated separation ("cracking") of the interwoven part of the two phase layer formed close to the substrate.

Osinski [6] has proposed a model for periodic layer formation in the diffusion couples $\mathrm{Fe}_{3} \mathrm{Si} / \mathrm{Zn}$ and $\mathrm{CO}_{2} \mathrm{Si} / \mathrm{Zn}$ based on the assumption of a periodic build-up and relaxation of stresses at the reaction interface. When the growing band has reached a critical thickness the stress developed in the diffusion zone becomes so large that it may cause blistering of the bands. After that the reaction can start afresh, forming intermetallic and another band, Another model was proposed by Kao and Chang [23]. They suppose a periodic thermodynamic instability of the substrate/product interface with subsequent new nucleation of the reaction layers. However, this model requires single-phase reaction layers and single-phase bands, which conflicts with the experimental observations.

Experimental observations lead to the conclusion that separating of the two-phase layers might indeed be attributed to stresses developed in the transition zone during reaction. When the reacting species diffuse intrinsically at a different rate, mass flow occurs within the diffusion zone. This requires that vacancies are created at one side of the diffusion zone and annihilated (at sinks, mainly dislocations) at the other side. The annihilation tends to contract the solid, thereby subjecting this region of the diffusion zone to tensile stress because the adjacent materials oppose volume change. By the same constraint the creation of vacancies leads to compressive stress in the other part of the diffusion zone.

It seems reasonable to link the periodic layer formation to the well-known Kirkendall effect which induces a shift of lattice planes towards the faster diffusing component. A first attempt in this direction has already been made by Slusarenko and Dunaev in the case of the $\mathrm{Mg} / \mathrm{Ni}_{50} \mathrm{CO}_{20} \mathrm{Fe}_{30}$ system [9]. Their explanation contains the concept of "concentration fluctuations" in the diffusion zone, resulting in the nucleation of the periodic bands. However, we believe that nucleation of phases is not necessary within the reaction zone because of the fact that the matrix is continuous and the band particles are formed at the substrate/reaction layer interface.

The problems associated with phase interface migration and the Kirkendall effect in binary two-phase systems have already been considered in detail [24]. An important conclusion from this work is that, depending upon the intrinsic diffusion coefficients for each component in each newly formed phase and the initial and interfacial compositions in the diffusion couple, the interphase interface must be able to create or annihilate vacancies. In general, for a diffusion-driven phase transformation the interface needs to satisfy at least three interrelated requirements [25]:

1) effect the vacancy balance

2) effect the necessary composition change

3) effect the required structure change

In the following we apply a similar approach in the systems exhibiting a periodic structure. In all cases one species ( $\mathrm{Zn}, \mathrm{Mg}, \mathrm{Pt}$ ) diffuses much faster than the others through the reaction layer in which the periodic bands are present. The flux of atoms of the most mobile component through the reaction layer towards the reaction interface implies a flux of vacancies in the opposite direction. In the case of $\mathrm{SiC} / \mathrm{Pt}$ diffusion couples the situation is more complicated because one more phase is formed in the diffusion zone next to $\mathrm{SiC}$. In $\mathrm{Pt}_{7} \mathrm{Si}_{3}, \mathrm{Pt}$ is the most mobile component. The situation may be different for $\mathrm{Pt}_{2} \mathrm{Si}$. In any case at least one reaction interface must act as a source of vacancies. The expected 
intrinsic fluxes in the vicinity of such an interface (e.g. $\mathrm{Pt}_{2} \mathrm{Si}_{2} \mathrm{Pt}_{7} \mathrm{Si}_{3}$ ) are shown schematically in fig. 10.

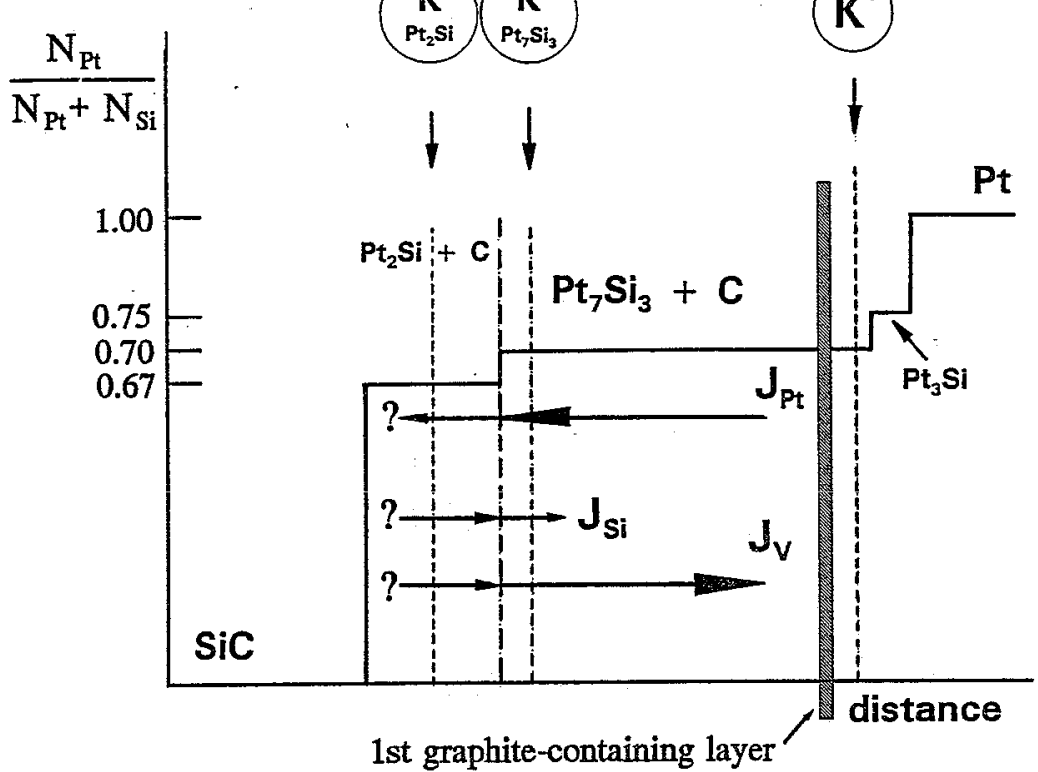

Fig. 10 Concentration profile (schematic) and expected intrinsic fluxes in the vicinity of the $\mathrm{Pt}_{2} \mathrm{Si} / \mathrm{Pt}_{7} \mathrm{Si}_{3}$ interface in a $\mathrm{SiC} / \mathrm{Pt}$ diffusion couple $\left(\mathrm{K}^{*}\right.$ denotes original metal/ceramic interface.

Bardeen and Herring [26] have shown that the forces arising form a non-equilibrium vacancy concentration will produce dislocation climb (thus altering the number of lattice sites) when the excess vacancy-concentration is $1 \%$ or even less. Later a thorough analysis of the role of interfacial dynamics in diffusion-driven phase transformations (for binary systems with a terminal solubility) was given by Pierraggi et al [27,28].

We note at this point that in all observed periodic structures the matrix phase is an ordered intermetallic. In other couples where periodic layer formation might be expected, e.g. $\mathrm{Co} / \mathrm{SiC}$ and $\mathrm{Fe} / \mathrm{SiC}$ the matrix was a solid solution (either disordered or ordered). The "particle phase" is of a different crystal system.The particles are in thermodynamic equilibrium with the intermetallic and may be considered as inert markers formed in situ inside the diffusion zone, which is evidenced by the fact that e.g. in $\mathrm{Fe}_{3} \mathrm{Si} / \mathrm{Zn}$ couples the bands continue through the $\delta / \zeta$ interface. A band of inert markers can be split as a result of the operation of the conventional Kirkendall-mechanism (fig. 10). Such a phenomenon has been observed by Bastin [29]. In a multiphase Ti-Ni diffusion couple he demonstrated the actual rupture of a tungsten marker wire as a result of different diffusion fluxes in the various phases.

A difference in vacancy fluxes on both sides of a reaction interface necessitates local climb processes involving misfit and/or misorientation dislocations at this interface [28]. These processes support the annihilation or creation of vacancies and lead to the development of elastic stress in adjoining layers. At a critical strain level dislocation glide may occur, returning dislocations to the interface and/or remove planes from the interface. Such a periodic stress build-up and relaxation during creation or annihilation of vacancies via 
dislocation climb and return glide to the interphase interface might be the cause of periodic splitting of the bands of inert markers that was observed in our experiments and so lead to a periodic pattern.

\section{Concluding remarks}

Vacancies and dislocations in intermetallic compounds present special features and a much more complex behaviour compared to pure metals. For example, in pure metals of simple cubic structure all lattice sites are equivaltent for the formation of vacancies, contrary to intermetallic compounds (ordered alloys) where the various sublattices are not equivalent. Despite difficulties to find a predictive model for the formation of periodic layered structures during solid state reactions they can be connected to:

1) A certain type of phase relations that allows to form a two-phase interwoven layer in the diffusion zone.

2) Large differences in the mobilities of the components leading to a large difference in vacancy fluxes on both sides of a reaction interface. The splitting up of markers occurs as a result of the operation of a Kirkendall-effect.

3) Mechanical stresses in the vicinity of the reaction interface due to dislocation climb and periodic relaxation via return glide to the reaction interface.

\section{Acknowledgement}

The investigation is supported by the Netherlands Foundation for Chemical Research (SON) with financial aid from the Netherlands organization for Scientific Research (NWO).

\section{References}

[1] J.S. Kirkaldy, L.C. Brown, Can. Met. Quart. 2, 89 (1963)

[2] C. Wagner, J. Electrochem. Soc. 103, 571 (1956)

[3] R.A. Rapp, A. Ezis, G.J. Yurek, Met. Trans A, 4A, 1283 (1973)

[4] F.J.J. van Loo, Progr. Solid St. Chem. 20, 47 (1990)

[5] K. Osinski, A.W. Vriend, G.F. Bastin, F.J.J. van Loo, Z. Metallkde. 73, 258 (1982)

[6] K. Osinski: The influence of aluminium and silicon on the reaction between iron and zinc, $P h D$ thesis, Eindhoven, the Netherlands , 1983

[7] M.R. Rijnders, F.J.J. van Loo, Scripta Met. Mater., accepted for publication

[8] S. Geller, Acta Cryst. 8, 83 (1955)

[9] E.M. Slusarenko, S.F. Dunaev, Vestn. Mosk. Univ. Ser. 2: Khim. 28, 512 (1987)

[10] S.A. Zver'kov, S.F. Dunaev and E.M. Slusarenko, Vestn. Mosk. Univ. Ser. 2: Khim. 29, 182 (1988)

[11] S.F. Dunaev, S.A. Zver'kov, J. Less Comm. Metals 153 (1989), 143

[12] R.L. Mehan, M.R. Jackson: A study of solid metal/ceramic interactions, final report, General Electric Co., New York, 1982

[13] R.C.J. Schiepers, F.J.J. van Loo, G. de With, J. Am. Ceram. Soc. 71, C-284 (1988)

T.C. Chou, A. Joshi and J. Wadsworth, J. Mater. Res. 8(4), 796 (1991)

T.C. Chou, J. Mater. Res. 5 (1990), 601

T.C. Chou, J. Mater. Sci. 26, 1412 (1991)

Binary alloy phase diagrams, T.B. Massalski, ed., J.I. Murray, L.H. Bennett, H. Baker, eds., American Society for Metals, 1986 
J.S. Kirkaldy, D.J. Young, Diffusion in the condensed state, the Institute of metals, London (1987)

R.E. Liesegang, Naturw. Wochenschr. 11, 353 (1896)

K. Jablczynski, S. Kobryner, Bull. Soc. Chim. France 33, 1592 (1923)

C. Wagner, J. Colloid Sci. 5, 85 (1950)

W. Ostwald, Lehrbuich der Allgemeinen Chemie, Engelmann Verlag, Leipzig (1897)

C.R. Kao, Y.A. Chang, Acta Metall. Mater. 41 (1993), 3463

[25] F.J.J. van Loo, B. Pierragi, Mat. Sci. Forum 155-156, 307 (1994)

[26] J. Bardeen, C. Herring: Diffusion in alloys and the Kirkendall effect, in: Imperfections in nearly perfect crystals, W. Shockley et al., eds.,261-288, Wiley, New York (1952)

B. Pierragi, R.A. Rapp, Acta Metall. Mater. 36, 1281 (1988)

B. Pierragi, R.A. Rapp, F.J.J. van Loo, J.P. Hirth, Acta Metall. Mater. 38, 1781 (1990)

G.F. Bastin: Diffusion in the titanium-nickel system, Ph.D thesis, Eindhoven, the Netherlands (1972) 